\title{
Variasi Bahasa SPG (Sales Promotion Girl) Di Ramayana Ciputat
}

\author{
SPG Language Variation in Ramayana Ciputat \\ Ghina Rizki Bhakti*1, Maya Novalia Pulungan ${ }^{2}$ \\ ${ }_{1,2}$ Program Studi Pendidikan Bahasa dan Sastra Indonesia, Fakultas Ilmu Tarbiyah dan Keguruan, \\ Universitas Islam Negeri Syarif Hidayatullah Jakarta, Indonesia \\ e-mail: *1 ginnarizkibhakti@gmail.com, ${ }^{2}$ mayanovalia19@gmail.com
}

\begin{abstract}
ABSTRAK
Setiap bahasa mempunyai ketetapan atau kesamaan dalam hal tata bunyi, bentuk, kata, kalimat, dan makna. Akan tetapi, karena berbagai faktor yang terdapat di dalam masyarakat seperti usia, pendidikan, agama, bidang kegiatan, dan profesi, serta latar belakang budaya daerah, maka bahasa menjadi tidak seragam. Manusia sebagai makhluk sosial memiliki kebutuhan untuk berinteraksi dengan sesamanya. Tentu saja manusia memerlukan bahasa sebagai alat komunikasi untuk menyampaikan pikiran, perasaan, dan keinginannya agar dapat melangsungkan hubungan dengan komunitasnya. Dalam kajian bahasa, persoalan variasi bahasa dibahas dalam bidang sosiolinguistik. Pada dasarnya, variasi bahasa merupakan wujud pendukung dari proses komunikasi. Variasi bahasa merupakan cerminan ketidakseragamannya suatu masyarakat yang disebabkan oleh lingkungan pemakai bahasa. Penelitian ini akan membahas tentang variasi bahasa SPG (Sales Promotion Girl) ditinjau dari segi pemakaian atau biasa disebut dengan fungsiolek, ragam, atau register. Tujuan dari penelitian ini adalah untuk medeskripsikan variasi bahasa SPG (Sales Promotion Girl) ditinjau dari segi pemakaian bahasa tersebut. Katakunci: sosiolinguistik, komunikasi, variasi bahasa, SPG (Sales Promotion Girl)
\end{abstract}

\begin{abstract}
Each language actually has a resolve or similarity in terms of sounds, formatting, grammar, sentence, and meaning. However, due to various factors in the language user community, such as age, education, religion, field of activity, and profession, as well as regional cultural background, the language becomes uniform. Humans as social beings have a need to interact with each other. Of course humans need language as a means of communication to convey their thoughts, feelings, and desires in order to establish relationships with their communities. In the study of language, the issue of language variation is discussed in the field of sociolinguistics. Basically, language variation is a supporting form of the communication process. Language variation is a reflection of the uniformity of a society caused by the language user environment. This research will discuss about the variation of SPG (Sales Promotion Girl) in terms of usage or commonly referred to as function, variety, or register. The purpose of this study is to describe the variation of SPG (Sales Promotion Girl) language in terms of language usage
\end{abstract}

Keywords: sociolinguistics, communication, language variation, SPG (Sales Promotion Girl)

\section{PENDAHULUAN}

Bahasa merupakan sarana komunikasi yang sangat penting dalam kehidupan manusia. Hampir dalam semua kegiatan manusia memerlukan bantuan bahasa. Baik dalam kehidupan sehari-hari, maupun dalam kegiatan khusus seperti kesenian dan ilmu pasti, bahasa merupakan kegiatan yang tidak dapat ditinggalkan. Dalam kehidupan sehari-hari di rumah, di pasar, dan di tempat hiburan, bahasa selalu dipergunakan orang. Kesenian, misalnya seni sastra, seni suara, dan seni pidato, pastilah memerlukan bahasa sebagai sarana utamanya. Bahkan matematika, dalam menyatakan perumusannya juga menggunakan bahasa. Sukar kita bayangkan manusia hidup tanpa bahasa.[1]

Perkembangan zaman telah membuat manusia semakin pintar dan kreatif. Dewasa ini, banyak kita temukan produk-produk ciptaan manusia, baik dalam negeri maupun luar negri yang mengundang perhatian di kalangan masyarakat. Beberapa produk yang dihasilkan berupa pakaian, makanan, bahkan alat-alat teknologi yang canggih. Kualitas yang dihasilkan pun 
beragam, dari yang berkualitas tinggi, menegah, dan rendah.Banyak perusahaan yang berlombalomba untuk menawarkan produk mereka kepada masyarakat. Berbagai cara dilakukan untuk memperomosikan produk-produk tersebut, baik melaluimedia elektronik seperti televisi, radio, dan handphone, maupun melalui media cetak seperti majalah, koran, dan brosur. Namun, demi mencapai pendapatan yang fantastis dari produk-produk yang dihasilkan, tidak sedikit perusahaan yang menggunakan jasa dari orang lain untuk memperomosikan barang-barang yang mereka hasilkan atau biasa dikenal dengan sebutan Sales Promotion Girl/Boy (SPG/SPB).

Sebagaimana kita ketahui bahwa munculnya profesi sales adalah untuk membantu suatu perusahaan memperomosikan produk-produk yang dihasilkan kepada masyarakat. Dapat dikatakan bahwa sales merupakan ujung tombak terhadap kemajuan suatu perusahaan.Berdasarkan hal tersebut, maka sarana yang digunakan para sales untuk memperomosikan produk-produk tersebut adalah bahasa, karena mereka bekerja dengan cara berinteraksi langsung kepada pelanggan.Maka dari itu, seseorang yang berprofesi sebagai sales perlu membekali diri dengan kemampuan berkomunikasi yang baik, karena untuk menarik hati pelanggan, sales perlu melakukan bujuk rayuan yang tinggi agar mereka mau membeli produk yang dipromosikan.

Jelas, bahwa bahasa sangat penting dalam kehidupan manusia untuk mencapai suatu tujuan. lebih lanjut, [2] Bahasa juga mempunyai fungsi tersendiri sesuai dengan konteks yang berhubungan dengan suatu kejadian di masyarakat. Jika dilihat dari segi tujuan, maka tidak menutup kemungkinan munculnya variasi dalam bahasa. Sebagaimana yang dituturkan oleh [3]bahwa bahasa itu bervariasi karena keragaman interaksi sosial yang dilakukan oleh masyarakatnya yang beragam. Hal ini dilatarbelakangi oeh tujuan masyarakat yang berbeda-beda ketika menggunakan bahasa. Salah satunya adalah bahasa digunakan dalam bidang perdagangan dengan tujuan memperoleh respon dari orang lain agar mau membeli produk-produk yang dipromosikan. Berbagai kata bujuk rayu dilontarkan oleh sales untuk menarik minat calon pembeli. Hal teserbut membuat terciptanya variasi bahasa dalam masyarakat. Telaah yang melihat bahasa terutama sebagai kegiatan masyarakat atau studi yang mempelajari hubungan antara bahasa dan masyarakat pemakainya dikenal dengan nama sosiolinguistik. Dalam proses komunikasi, seseorang atau masyarakat pemakai bahasa memiliki cara tersendiri dalam mengungkapkan pemikiran, ide, dan perasaannya. Hal ini yang menarik hati peneliti untuk menganalisis variasi bahasa pada salah satu SPG di Ramayana Ciputat.

Sosiolinguistik merupakan ilmu antardisiplin antara sosiologi dan linguistik, dua bidang ilmu empiris yang mempunyai kaitan sangat erat[3]. Maka, untuk mengetahui apa itu sosiolinguistik, perlu terlebih dahulu dibicarakan apa yang dimaksud dengan sosiologi dan linguistik. Tentang sosiologi telah banyak variasi batasan yang dibuat oleh para sosiolog, tetapi intinya adalah bahwa sosiologi adalah kajian yang objektif dan ilmiah mengenai manusia di dalam masyarakat dan mengenai lembaga-lembaga, serat proses sosial yang ada di dalam masyarakat. Sosiologi berusaha mengetahui bagaimana masyarakat itu terjadi, berlangsung, dan tetap ada. Dengan mempelajari lembaga-lembaga sosial dan segala masalah sosial dalam satu masyarakat, akan diketahui cara-cara manusia menyesuaikan diri dengan lingkungannya, bagaimana mereka bersosialisasi, dan menempatkan masing-masing diri di dalam masyarakat. Sementara itu, linguistik merupakan bidang ilmu yang mempelajari bahasa, atau bidang ilmu yang mengambil bahasa sebagai objek kajiannya. Dengan demikian, secara mudah dapat dikatakan bahwa sosiolinguistik adalah bidang ilmu antardisiplin yang mempelajari bahasa dalam kaitannya dengan penggunaan bahasa itu di dalam masyarakat.[4] Sosiolinguistik dapat juga dikatakan sebagai ilmu yang mempelajari dan membahas aspek-aspek kemasyarakatan bahasa, khususnya perbedaan-perbedaan (variasi) yang terdapat dalam bahasa yang berkaitan dengan faktor-faktor kemasyarakatan (sosial). [5]

Sesuai dengan namanya, sosiolinguistik mengkaji bahasa dengan memperhitungkan hubungan antara bahasa dengan masyarakat, khususnya dengan masyarakat penutur bahasa itu., sebagaiman yang dikatakan [6] bahwa sosiolinguistik mempertimbangkan keterkaitan antara dua hal, yakni dengan linguistik untuk segi kebahasaannya dan dengan sosiologi untuk segi kemasyarakatannya. 
Setiap bahasa sebenarnya mempunyai ketetapan atau kesamaan dalam hal tata bunyi, tata bentuk, tata kata, tata kalimat, dan tata makna. Akan tetapi, karena berbagai faktor yang terdapat di dalam masyarakat pemakai bahasa itu, seperti usia, pendidikan, agama, bidang kegiatan, dan profesi, serta latar belakang budaya daerah, maka bahasa itu menjadi tidak seragam [7]. Masyarakat menggunakan bahasa untuk berhubungan dan bekerja sama dengan masyarakat lain. Masyarakat yang satu dengan masyarakat yang lain pada kenyataannya beraneka ragam. Keberadaan masyarakat yang beraneka ragam melahirkan variasi-variasi dalam penggunaan bahasa. Timbulnya variasi bahasa disebabkan oleh para penuturnya yang tidak homogen dan juga disebabkan oleh kegiatan interaksi sosial yang mereka lakukan beraneka ragam. Tidak ada masyarakat yang sama, demikian pula bahasa itu bervariasi[8].

Banyak kriteria dan patokan yang dipakai oleh para ahli untuk menguji variasi atau ragam bahasa yang terdapat di dalam bahasa. Begitu juga istilah yang digunakan sering kali tidak sama. Ada istilah yang sama digunakan untuk konsep yang berbeda, tetapi ada juga istilah yang berbeda digunakan untuk konsep yang sama. Variasi bahasa dibedakan dari segi penutur, pemakaian, keformalan, dan dari segi sarana [9].

1. Variasi dari Segi Penutur

Variasi bahasa pertama berdasarkan penuturnya adalah variasi bahasa yang disebut idiolek, yakni variasi bahasa yang bersifat perseorangan. Menurut konsep idiolek, setiap orang mempunyai variasi bahasa atau idioleknya masing-masing. Variasi idiolek ini berkenaan dengan "warna" suara, pilihan kata, gaya bahasa, susunan kalimat, dan sebagainya. Namun yang paling dominan adalah "warna" suara itu, sehingga jika kita dapat mengenali dengan seseorang tersebut tanpa harus melihat orang tersebut kita dapat mengenalinya [8]. Variasi bahasa kedua berdasarkan penuturnya disebut dialek, yakni variasi bahasa dari sekelompok penutur yang jumlahnya relatif, yang berada pada satu tempat, wilayah, atau area tertentu, karena dialek ini lazim disebut dialek areal, dialek regional, atau dialek geografi. Variasi ketiga berdasarkan penutur disebut kronolek atau dialek temporal yakni variasi bahasa yang digunakan oleh kelompok sosial pada masa tertentu.[8]

2. Variasi dari Segi Pemakaian

Variasi bahasa ini merupakan variasi bahasa yang berkaitan dengan pemakaiannya. . Variasi ini biasanya dibicarakan berdasarkan bidang penggunaan, gaya, atau tingkat keformalan, dan sarana penggunaan. Variasi bahasa berdasarkan bidang pemakaian ini adalah menyangkut bahasa itu digunakan untuk keperluan atau bidang apa. Misalnya, bidang sastra, jurnalistik, militer, pertanian, perdagangan, atau pendidikan. Variasi bahasa berdasarkan bidang kegiatan ini yang paling tampak cirinya adalah dalam bidang kosakata. setiap bidang kegiatan biasanya mempunyai sejumlah kosakata khusus atau tertentu yang tidak digunakan dalam bidang lain [8]. Variasi bahasa berdasarkan fungsi lazim disebut register. Dalam pembicaraan tentang register ini biasanya dikaitkan dengan masalah dialek. Kalau dialek berkenaan dengan bahasa itu digunakan oleh siapa, di mana, dan kapan, maka register berkenaan dengan masalah bahasa itu digunakan untuk kegiatan apa.

3. Variasi dari Segi Keformalan

Menurut Martin Joos dalam bukunya The Five Clocks [8] membagi variasi bahasa menjadi lima jenis style, yaitu ragam beku, resmi, usaha, santai, dan akrab. Dalam bahasa Indonesia pun gaya yang demikian dapat kita bagi atas lima tingkat sebagai berikut [10] :

a) Ragam beku (frozen) iala ragam bahasa terresmi yang digunakan dalam situasi-situasi yang khidmat dan upacara-upacara resmi. Misalnya undang-undang, akte notaris, dan upacara resmi.

b) Ragam resmi (formal) ialah ragam bahasa yang dipakai dalam pidato kenegaraan., rapat dinas, atau rapat resmi pimpinan suatu badan.

c) Ragam usaha (consultative) adalah ragam bahasa yang sesuai dengan pembicaraanpembicaraan biasa digunakan di sekolah, perusahaan, dan rapat-rapat usaha yang berorientasi kepada hasil atau produksi; dengan kata lain, ragam ini berada pada tingkat yang paling operasional. 
d) Ragam santai (casual) adalah ragam bahasa santai antarteman dalam berbincangbincang, rekreasi, berolah raga, waktu santaidan sebagainya.

e) Ragam akrab (intimate) adalah ragam bahasa digunakan oleh penutur yang sudah akrab, seperti anggota keluarga atau teman karib.

4. Variasi dari Segi Sarana

Variasi bahasa dapat pula dilihat dari segi sarana atau jalur yang digunakan. Dalam hal ini, dapat disebut adanya ragam lisan dan ragam tulis, atau juga ragam dalam berbahasa dengan menggunakan sarana atau alat tertentu. Adanya ragam bahasa lisan dan ragam bahasa tulis didasarkan pada kenyataan bahwa bahasa lisan dan bahasa tulis memiliki wujud struktur yang tidak sama[10].

Perusahaan dalam memasarkan suatu produk memerlukan beberapa aktivitas yang melibatkan berbagai sumber daya manusia. Sebagai fenomena yang berkembang pada saat ini, dalam pemasaran terdapat suatu bagian yang memiliki keterkaitan langsung dengan konsumen dalam mempromosikan suatu produk yaitu Sales Promotion Girl selanjutnya disingkat SPG. Profesi ini biasanya menggunakan wanita yang mempunyai karakter fisik yang menarik sebagai usaha untuk menarik perhatia konsumen. Nitisemito berpendapat bahwa SPG sebagai salah satu pendukung pemasaran suatu produk maka diperlukan tenaga promosi suatu produk sehingga mampu menarik konsumen. Selanjutnya, dengan kemampuan berpomosi yang dimiliki seorang SPG akan mampu memberikan berbagai informasi yang berkaitan dengan produk. [9]

Seorang Sales Promotion Girl dituntut untuk mempunyai tingkat kecerdasan yang tinggi, terutama terhadap pengetahuan produk yang dipromosikan maupun yang dipasarkan dan juga mempunyai penampilan fisik yang mendukung terhadap karakter produk. Sales Promotion Girls harus mencerminkan citra yang baik bagi merek atau brand yang dipasarkan. Penampilan, tutur kata, pengetahuan dan memberikan pelayanan yang baik agar membangkitkan image yang positif bagi konsumen. Sales Promotion Girls mempunyai deskripsi pekerjaan sebagai berikut:

1. Promosi

Berpromosi adalah hal utama yang harus dikerjakan oleh seorang Sales Promotion Girls ia wajib melakukan jemput bola dan segera berinteraksi dengan konsumen untuk tujuan mempromosikan produknya. Sales Promotion Girls dalam aktivitasnya tentunya membutuhkan sampel produk yang akan digunakan dalam berpromosi. Jika ia berada di store maka contoh produk riil akan terlihat, biasanya perusahaan juga menyediakan contoh produk perpieces atau perusahaan menggunakan tester untuk memandu konsumen dlam mengambil keputusan pembeli. Sales Promotion Girl akan memelihara dan mengelola tester ini untuk kepentinga dalam aktivitas bekerja. Jadi meskipun ia bertugas untuk mempromosikan produk, ia tidak hanya mempromosikan tetapi ia juga harus melihat persiapan secara keseluruhan.

2. Penjualan atau Selling

Alurnya SPG memperkenalkan terlebih dahulu, jika berminat SPG akan menjual produk itu. Sehingga dalam praktinya, jika seoarang SPG tidak berhasil menjual maka ia tidak terlalu pusing sebab target ia adalah memperkenalkan dan kemudian menjual.

3. Merchandising

Dalam hal ini SPG harus membuat display produk sedemikian rupa agar terjadi pembelian tak terencana oleh konsumennya. Tujuan dari mengubah iklan menjadi penjualan. Terjadinya pembelian tak terencana, memperkuat citra produk, dan menaikkan penjualan.

4. Persediaan produk atau ratasi stok

Menurut Frans dalam [11] bahwa SPG menggunakan ABC penjualan untuk mempertahankan stok. Artinya SPG segera mengklarifikasi produk mana saja yang merupakan urutan pertama memiliki pelanggan paling banyak dengan mengkategorikan huruf $\mathrm{A}$. Kemudian yang kedua dengan huruf $\mathrm{B}$ dan yang ketiga dengan huruf $\mathrm{C}$ serta yang kurang laku dengan huru D. Menggunakan klasifikasi ini akan sangat membantu SPG dalam menentukan produk mana saja yang perlu dipesan banyak dan sedikit tentunya setelah mengetahui data penjualan dari pihak store. 
Ramayana Lestari Sentosa adalah jaringan toko swalayan yang memiliki banyak caang di Indonesia. Ramayana Lestari Sentosa Tbk (RALS) didirikan 14 Desember 1983 dan mulai beroperasi secara komersial pada tahun 1983. Kantor pusat Ramayana berlokasi di Jl. K.H. Wahid Hasyim No. 220 A-B, Jakarta 10250 - Indonesia. Selain department store yang menjual produk sandang seperti baju dan sepatu , Ramayana juga memiliki supermarket atau pasar swalayan yang menjual kebutuhan pangan da sehari-hari. Supermarket milki Ramayana itu disebut Ramayana Supermarket. Grup usaha Ramayanan terdiri atas Ramayana, Robinson, dan Cahaya - baik dalam bentuk department store maupun supermarket. [12]

\section{METODOLOGI PENELITIAN}

Penelitian ini menggunakan metode deskriptif analisis. Metode ini dilakukan dengan cara mendeskripsikan data-data yang sudah didapat disusul dengan analisis. Deskriptif analitik berarti menguraikan untuk memberikan pemahaman dan penjelasan melalui kajian sosiolinguistik. Sumber data yang digunakan dalam penelitian ini yaitu data primer dan sekunder. Data primer berupa rekaman bahasa SPG di Ramayana Ciputat yang sudah ditranskrip, sedangkan data sekunder yang digunakan adalah buku-buku yang relevan dengan kajian yang akan dilakukan

\section{HASIL DAN PEMBAHASAN}

Penelitian terhadap variasi bahasa SPG di Ramayana Ciputat akan dianalisis melalui segi pemakainnya. Penelitian ini akan difokuskan pada variasi penggunaan kosakata dan kalimat yang dilontarkan oleh SPG di Ramayana Ciputat. Variasi bahasa berdasarkan segi pemakain biasa juga disebut dengan fungsi, ragam, atau register Variasi ini berarti membicarakan bidang pemakaian, gaya, tingkat keformalan, dan sarana penggunaan. Variasi bahasa berdasarkan bidang pemakaian menyangkut bahasa itu digunakan untuk bidang apa. Berikut dipaparkan penggunaan variasi bahasa SPG dan penjelasannya berdasarkan segi pemakaian:

\section{"Bagi para pengunjung Ramayana, kali ini kita hadir dengan beragam diskon barang- barang branded. April ceria ini Ramayana ada cuci gudang besar-besaran dengan diskon hingga 75\%, Bapak-Ibu."}

Penggunaan variasi bahasa dari segi pemakaian pada kutipan di atas, terdapat pemakainan kosakata diskonyang biasa digunakan pada bidang perdagangan atau kegiatan jual-beli. Diskon sering dilontarkan oleh para penjual/pedagang ketika sedang menawarkan barang dagangan mereka, baik di pasar, di toko, atau di pusat perbelanjaan lainnya. Kosakata Diskon dalam KBBI berarti potongan harga. Potongan harga tersebut merujuk pada setiap barang yang dijual oleh para penjual agar produknya diminati oleh masyarakat. Potongan harga yang diberikan juga beragam, mengikuti situasi yang sedang terjadi.

Penggunaan variasi bahasa SPG di Ramayanan Ciputat juga terlihat pada kata cuci gudang. Istilah cuci gudang sudah melekat pada masyarakat yang gemar membeli barang di pusat-pusat perbelanjaan. Kata ini lazim kita temukan dalam dunia promosi barang, seperti pakaian, sepatu, tas, dan handphone. Jika diartikan secara harfiah, cuci gudang merujuk pada kegiatan membersihkan gudang dengan cara mencuci gudang, dikarenakan kotor atau berbau tidak sedap. Namun, arti tersebut tidak sepenuhnya benar. Kegiatan cuci gudang bukan berarti karena gudang tersebut kotor, namun karena gudang itu sudah menumpuk barang jualan yang belum terjual. Hal ini mungkin disebabkan stok barang terlalu banyak, sementara pembelinya kurang. Mungkin juga disebabkan model barangnya yang tidak digemari oleh konsumen. Menghindari kerugian terhadap produk-produk yang dihasilkan, maka para penjual melakukan trik perdagangan dengan menggunakan istilah cuci gudang yang bertujuan untuk menarik hati para konsumen untuk membeli produk-produk mereka.

Variasi bahasa yang digunakan oleh SPG di Ramayana Ciputat juga terlihat pada kutipan berikut: 
"Silakan, kita hak segala bangsa, jadi semuanya boleh belanja di Ramayana. Merdeka! Ayo silakan yang mau baju-baju murah ya. Diskonnya dua kali lipat ya, baju anak juga. Belanja di Ramayana bisa keren."

Pada kutipan di atas, terdapat kalimat hak segala bangsa. Kalimat tersebut biasa ditemukan dalam bidang-bidang kemanusiaan. Kata hak berarti berwewenang atau memiliki kekuasaan. Seluruh masyarakat mempunyai wewenang dan kekuasaan di dalam bangsanya. Hak tersebut tidak pandang bulu, baik perempuan, laki-laki, tua, muda, cantik, tampan, dan sebagainya memiliki kekuasaan di dalam negerinya. SPG di Ramayana Ciputat ketika menawarkan berbagai produk kepada pengunjung, mennggunakan kalimat hak segala bangsa. Pemilihan kalimat tersebut merupakan salah satu cara perusahaan untuk menarik hati pengunjung agar mau berbelanja produk mereka. Setiap pengunjung, baik tua-muda, miskin-kaya, cantik-jelek berhak atau memiliki kewenangan untuk berbelanja di Ramayana tanpa harus mengeluarkan uang banyak, karena mereka memberikan harga yang murah.

Ketika memperomosikan barang-barang, SPG di Ramayana juga menggunakan kata merdeka. Kata ini merujuk pada bidang kenegaraan. Kata merdekaberarti bebas dari penjajahan, perhambaan, dan sebagainya atau tidak terikat oleh pihak tertentu. Merdekasangat identik dengan kebebasan suatu negara dari penjajahan, sehingga menjadi negara yang mandiri dan berdaulat. Merdeka adalah tujuan hidup masyarakat. Kata ini juga sering disepadankan dengan pertaruhan nyawa, karena ada makna perjuangan atau pertarungan yang terkandung dalam kalimat tersebut. Ketika SPG Ramayana menggunakan kata merdeka, artinya ia memberikan pernyataan bahwa masyarakat bebas berbelanja di Ramayan dengan harga murah dan beragam diskon yang disediakan, baik itu berbelanja baju, tas, sendal, maupun sepatu. Semua kalangan masyarakat tidak perlu khawatir dengan harga produk yang ada di Ramayana, karena semuanya diberikan dengan harga murah dan boleh dimiliki oleh siapapun.

Selain penggunaan variasi bahasa dalam bidang perdagangan, kemanuasiaan, dan kenegaraan yang telah dipaparkan di atas, ternyata SPG di Ramayana Ciputat juga menggunakan variasi bahasa dalam bidang elektronik ketika memperomosikan produk-produk kepada pengunjung. Berikut kuripannya:

"Silakan langsung naik ke lantai tiga yo. Ada koleksi sandal sepatunya. Ayo lima menit nih waktunya akan kita akhiri diskon sepatu sandalnya nih ya. Kita akan kembali ke laptop. Ayo silakan yang cari kaos-kaos oblong juga nih, hanya tiga puluh ribu. Iya kita akhiri dulu untuk diskon sepatu sandalnya. Kita kembali ke laptop."

Kosakata laptop sering ditemukan dalam bidang elektronik atau orang-orang yang bekerja dibidang elektronik. Laptop atau komputer jinjing adalah komputer bergerak yang berukuran relatif kecil dan ringan, beratnya berkisar 1-6 kg. Sementara itu, istilah kembali ke laptop merupakan kalimat yang ditujukan kepada penulis. Seringkali seseorang yang memiliki tugas untuk menulis di laptop merasa jenuh, lelah, atau bosan, namun banyak tuntutan tugas yang harus diselesaikan. Menghilangkan semua rasa itu, maka para penulis mencoba berhenti sejenak dari aktivitas di depan layar laptop. Setelah kondisi badan sudah kembali segar, rasa jenuh, lelah, dan bosan hilang, maka penulis harus kembali lagi ke laptop untuk menyelesaikan tuntutan tugas yang ada. Dalam perdagangan, seperti yang diucapkan oleh SPG di Ramayana, istilah kembali ke laptop berarti kembali ke awal, kembali kepada keadaan awal, atau kembali kepada aturan awal. Istilah dari SPG tersebut merujuk kepada makna harga barang yang memiliki diskon, namun karena waktu untuk barang-barang diskon tersebut terbatas, yaitu tersisa lima menit lagi, maka harga barang-barang itu pun akan kembali normal. Tidak ada diskon kepada pengunjung setelah lewat dari waktu yang ditentukan, karena harga barangnya pun akan kembali seperti harga awal.

Ada juga kosakata dari bahasa gaul yang digunakan oleh SPG di Ramayana ketika menawarkan produk-produk mereka kepada pengunjung. Seperti dalam kutipan berikut:

"Kita menyediakan barang-barang berkualitas, barang-barang branded dengan harga yang murah. Nggak usah khawatir dengan tanggal tua dan tanggal muda ya bu. Di sini 
harganya murah-murah. Siapa aja bisa belanja, bisa tampil kece, tampil cantik di Ramayana ya."

Kata kece merupakan akronim dari "keren cekali". Kata "cekali" seharusnya memiliki fonem awal /s/, namun untuk menimbulkan kesan gaul dan menarik maka diganti menjadi fonem /c/. Hal ini disebabkan dalam abjad Inggris, fonem /c/ memiliki kesamaan pengucapan dengan fonem /s/. Kece merupakan kata sifat yang berarti keren sekali atau cantik sekali. Kata ini biasa digunakan oleh para remaja untuk mengomentari penampilan seseorang atau menunjukkan kekaguman terhadap penampilan. Kata kecedigunakan oleh SPG mempunyai tujuan agar para masyarakat mau berbelanja di Ramayana, karena barang-barang yang dijual bisa membuat penampilan mereka keren dan cantik.

Variasi bahasa SPG di Ramayana Ciputat juga terdapat penggunaan register, yaitu variasi bahasa berdasarkan fungsi. Dalam pembicaraan tentang register ini biasanya dikaitkan dengan masalah dialek. Dialek berkenaan dengan bahasa itu digunakan oleh siapa, di mana, dan kapan, maka register berkenaan dengan masalah bahasa itu digunakan untuk kegiatan apa. Berikut variasi bahasa SPG di Ramayana Ciputat berdasarkan register:

"Diskon hingga 70\%. Pake tanda diskon ya. Bu, minta tanda diskon dulu, jangan langsung ke kasir. Jangan ampe lupa. Nanti kaga dapet diskon. Minta tanda diskon dulu, baru ke kasir ye bu."

Pada kutipan di atas, terdapat kata ampe, kaga, dan ye. Kata tersebut merupakan bentuk yang biasa digunakan oleh budaya Betawi. Ampe berasal dari kata Betawi Betawi yang berarti "sampai", $\boldsymbol{k a g} \boldsymbol{a}$ adalah sebutan dalam budaya Betawi yang berarti "tidak", dan ye juga sering digunakan oleh suku Betawi yang berarti "ya". Dalam pemakaian dialek Betawi, banyak menggunakan akhiran $\boldsymbol{e}$, seperti kosakata Ampe dan ye. Register ini digunakan oleh SPG di Ramayana Ciputat ketika melihat seorang ibu yang berbelanja dan sudah menemukan barang diskon yang diinginkan, namun langsung menemui kasir tanpa meminta terlebih dahulu tanda diskon dari salah satu petugas Ramayana. Padahal, sudah diberitahukan bahwa barang diskon yang ingin dibeli harus memakai tanda diskon, agar petugas kasir mengetahui bahwa barang tersebut merupakan barang diskon. Pemakaian kata dialek Betawi yang diucapkan oleh SPG di Ramayana disebabkan ia sering menggunakan dialek tersebut, sehingga dalam percakapan menggunakan dialek Betawi, atau barangkali SPG tersebut berasal dari suku Betawi sehingga mempengaruhi ke dalam percakapannya

\section{SIMPULAN}

Berdasarkan hasil analisis, penelitian ini dapat disimpulkan bahwa banyak ditemukan istilah-istilah atau kosakata dalam bidang tertentu yang dipakai oleh SPG di Ramayana Ciputat ketika mempromosikan barang-barang yang mereka jual. Kosakata yang dipakai adalah bidang perdagangan. Namun beberapa kosakata bidang, seperti kemanusiaan dan kenegaraan juga dipakai oleh SPG ketika mempromosikan barang-barang mereka. Pemilihan istilah-istilah atau kosakata tersebut dalam rangka menarik minat dan membujuk para pengunjung Ramayana agar mereka mau membeli barang-barang yang ditawarkan. Selain itu, dalam bahasa SPG di Ramayana Ciputat juga ditemukan variasi bahasa berdasarkan fungsi atau register. SPG tersebut menggunakan kosakata yang berasal dari budaya Betawai, hal ini disebabkan oleh kebiasaannya menggunakan bahasa dengan dialek Betawi atau barangkali SPG tersebut berasal dari suku Betawi.

\section{REFERENCES}

[1] A. HP and Alex Abdullah, Linguistik Umum. Jakarta: Erlangga, 2013.

[2] R. R. Yono, "PENDAYAGUNAAN KONTEKS DALAM TINDAK TUTUR ANAK USIA 7 TAHUN DI MADRASAH DINIYAH TA'LIMUL HUDA DESA 
RANDUSANGA WETAN,” SEMANTIKA, vol. 1, no. 1, pp. 20-30, 2019.

[3] T. Khoirurrohman and M. Rohmad Abdan, "Analisis Pemakaian Variasi Bahasa Slang Pada Remaja Desa Kalinusu: Kajian Sosiolingustik,” J. Ilm. Semant., vol. 1, no. 02, 2020.

[4] P. J. Sari, "Sosiolinguistik Sebagai Landasan Dasar Pendidikan Di Sekolah Dasar," in Prosiding Seminar Nasional Bulan Bahasa UNIB, 2015, pp. 200-207.

[5] Waridah, "Penggunaan Bahasa dan Variasi Bahasa dalam Berbahasa dan Berbudaya," Simbolika, vol. 1, no. 1, pp. 84-92, 2015, doi: https://doi.org/10.31289/simbollika.v1i1.

[6] S. Anwar and R. Pertiwi, "Campur Kode," J. Penelit. Pendidik. Indones., vol. 2, no. 1, pp. 1-11, 2017, doi: Prefix: 10.47403/jppi.

[7] F. Munte, Y. Morelent, and Dainur Putri, "PENULISAN KESALAHAN KATA PADA MEDIA MASSA KORAN SINGGALANG EDISI BULAN MEI 2014,” Padang, 2014.

[8] D. R. Setiawati, "Variasi Bahasa Dalam Situasi Tidak Formal Pada Mahasiswa Program Studi Pendidikan Bahasa Indonesia Di Universitas Tadulako," J. Bhs. dan Sastra, vol. 1, no. $1, \quad$ pp. $1-11, \quad 2019, \quad$ doi: http://jurnal.untad.ac.id/jurnal/index.php/BDS/article/view/12245.

[9] W. Asriyani, "Tuturan Direktif SPG Make Up di Supermarket Kota Tegal," Universitas Negeri Semarang, 2015.

[10] achmad zulakbar, "VARIASI BAHASA DALAM KOMUNIKASI KOMUNITAS DANZ BASE MAKASSAR: TINJAUAN SOSIOLINGUISTIK," UNIVERSITAS HASANUDDIN MAKASSAR, 2018.

[11] Reza Rizki Pahlevi, "ANALISIS PERAN SALES PROMOTION GIRL (SPG) TERHADAP MEDIA PEMASARAN DALAM MENINGKATKAN OMSET PERUSAHAAN (Studi Kasus PT Multi Media Seluler Kota Metro),” INSTITUT AGAMA ISLAM NEGERI (IAIN) METRO, 2019.

[12] P. Pamungkas, "Ramayana Lestari Sentosa adalah jaringan toko swalayan yang memiliki banyak cabang di Indonesia," tribunnewswiki.com, Jakarta, Mar. 2020. 